\title{
MODERNISATION OF PUBLIC BUILDINGS IN POLISH TOWNS AND THE CONCEPT OF SUSTAINABLE BUILDING
}

\author{
Justyna ChodKowsKa-MiszczuK, DANiela SzYMańSKa \\ Department of Urban Studies and Regional Development, Faculty of Earth Sciences, Nicolaus Copernicus \\ University, Toruń, Poland
}

Manuscript received: January 16, 2014

Revised version: June 10, 2014

\begin{abstract}
Chodkowska-Miszczuk J., SzYmańska D., 2014. Modernisation of public buildings in Polish towns and the concept of sustainable building. Quaestiones Geographicae 33(4), Bogucki Wydawnictwo Naukowe, Poznań, pp. 89-99, 3 photos, 6 figs. DOI 10.2478/quageo-2014-0052, ISSN 0137-477X.

AвSTRACT: This article aims to identify the scale of energy efficiency improvements in public buildings in Polish towns as representative of sustainable building. The study area is investigated from the perspective of challenges arising from the current policy in the EU. The article indicates that, given the age of public buildings in Poland, the best way to implement the concept of sustainable building is to improve their present stock. The modernisation of public buildings is discussed in terms of project location, project value, sources of funding (including EU funds), and the use of buildings undergoing modernisation. According to the research findings, the implementation of the sustainable building concept is determined by both, exogenous factors (EU directives and domestic laws, etc.) and endogenous ones (e.g. human resources and their quality).
\end{abstract}

KEY WORDS: Poland, towns, public buildings, sustainable building

Daniela Szymańska, Department of Urban Studies and Regional Development, Faculty of Earth Sciences, Nicolaus Copernicus University, Lwowska 1,87-100 Toruń, Poland; e-mail: dani@umk.pl

\section{Introduction}

The socio-economic development of countries and regions brings about major changes in the construction sector. As a result, new buildings are constructed and put into service and the existing ones are improved. Because the construction and renovation of buildings in highly developed countries follow the principles of sustainable development, resource- and energy-saving solutions become increasingly common. The most frequent approach to making the existing stock of buildings more energy efficient is based on thermal improvements (TI).
Measures aimed to raise the energy performance of buildings are particularly important in Poland today, because the construction sector is the most energy-intensive of all economic sectors in the country. The amount of energy used to construct and operate buildings exceeds $40 \%$ of final energy consumption in Poland (Central Statistical Office 2011), a rate similar to those noted in the EU and other western countries. The construction and operation of buildings accounts for $42 \%$ of all energy consumed in the EU Member States, 37\% in the USA (Commission 2007b), and $31 \%$ in Japan (Juan et al. 2010). The IEA and OECD predict (IEA 2010) that by the year 2050 
the construction industry's demand for energy may reach as much as $60 \%$, leaving transport and manufacturing behind.

The amount of energy consumed by the construction sector is therefore substantial, mainly because of the need to supply heat, ventilation, cooling and usable hot water. It is worth noting, however, that the structure of energy demand depends on the use of a building. Residential buildings are different from non-residential, e.g. public, ones because most of their energy demand arises from the necessity to deliver heat and usable hot water. In public buildings, most energy is consumed by the delivery of electricity, ventilation and air-conditioning (AC). The AC systems contribute to the steadily rising demand for energy, because public buildings are commonly required to be provided with them. In the existing and new buildings, the systems account for $15 \%$ and $22 \%$, respectively, of energy consumption (BPIE 2011). In some types of public buildings, e.g. health-care facilities (hospitals, outpatient clinics), nursing homes, and child-care establishments, the delivery of heat and hot water consumes a major portion of energy, so they are increasingly equipped with installations such as solar collectors that allow hot water to be obtained from renewable energy sources (Chodkowska-Miszczuk, Szymańska 2012).

This article aims to identify the scale of energy efficiency improvements carried out in public buildings in Polish towns as representative of sustainable building in relation to challenges arising from EU policy. Because older buildings predominate in the age structure of public buildings in Poland $(40 \%$ of them were constructed before 1960, 35\% in the years 1961-1990, and 25\% between 1991 and 2010), an assumption is made that the degree to which the sustainable building concept and energy efficiency improvements in public buildings are implemented depends on repairs and thermal modernisation works carried out in those buildings. The article attempts to establish how extensive the processes are, the dif-

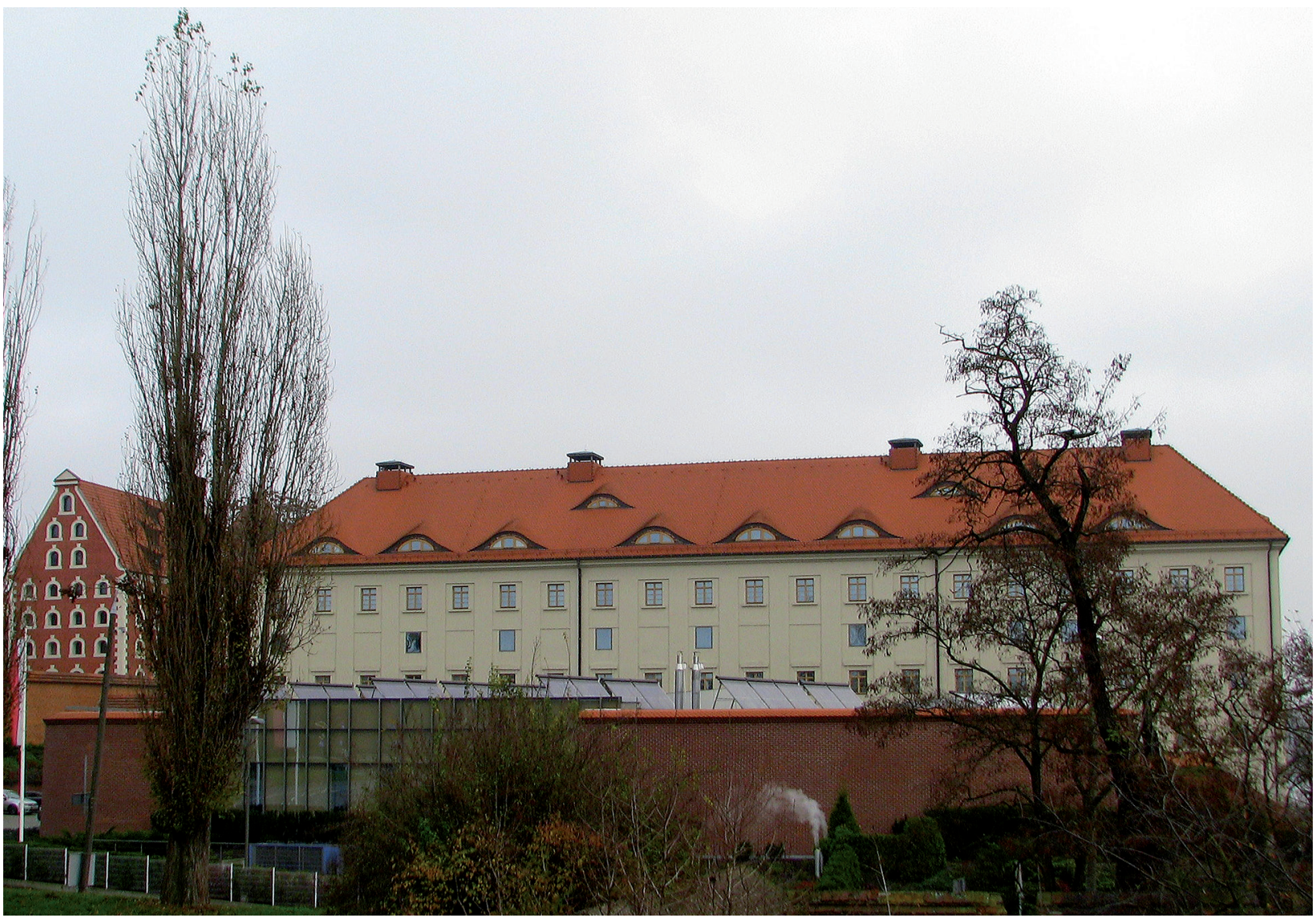

Photo 1. A passive public building - the hotel Bulwar in Torun. An example of combining the history of a building with the requirements of a modern highest-standard hotel.

Source: photo by D. Szymańska, 10 October 2013. 
ferences between them, as well as major factors behind their occurrence, including the role of local governments and EU funding. The improvements in public buildings are considered in terms of project location, project value, the sources of funding (including EU grants) and the particular use of buildings.

Because of its aforementioned high demand for energy, the construction sector has a special role to play in activities aimed to implement sustainable development principles. Generating some $10 \%$ of the EU's GDP and employing $7 \%$ of its workforce (Commission 2007b), the sector is central to the national economies of Member States, including Poland, and to the European Union as a whole. It is unique in its ability to implement innovative solutions, including the use of renewable energy sources, and its growth generates substantial economic and social benefits.

Sustainable building addresses environmental issues by introducing new technologies, improving energy efficiency, and increasing the share of energy derived from renewable sources. The buildings can and should generate their own energy, receive and reuse their own water, use recycled materials, and compensate for the emission of $\mathrm{CO}_{2}$ in the production of construction materials (Coimbra, Almeida 2013). Moreover, the term 'sustainable building' involves wider issues because it is also used and applied to economic and social areas (Zmeureanu 2006; Hepbasli 2012).
Building activity following the principles of sustainable development offers notable economic effects (including financial savings), as well as improving the life quality of building users, including elderly and disabled people. This aspect is particularly important today, because a person living in a highly-developed country spends an average of almost $80 \%$ of their lifetime indoors (Commission 2007b). These factors have contributed to sustainable building and renewable energy being included in the Lead Market Initiative for Europe programme (Commission 2007a) as one of six major economic areas in the EU.

A stepping stone in the development of sustainable building is a passive building that has recently gained in popularity also in Poland (Szymańska 2013; Photo 1). Passive building technologies are predominantly used in West European countries, mainly in Germany and Austria. In Germany, the Passive House Institute has been set up to promote their use. The best known definition of a passive building has been put forward by Wolfgang Feist, the founder of the Institute: a passive building ensures thermal comfort in both winter and summer with minimal consumption of energy (http:/ / passiv.de). It needs to be noted that the energy efficiency of a passive building is some $85 \%$ greater than that of a standard one (Nowak 2010). The first certified passive public building in Poland (a sports hall, quality certified by the Passive House Institute) was erected in

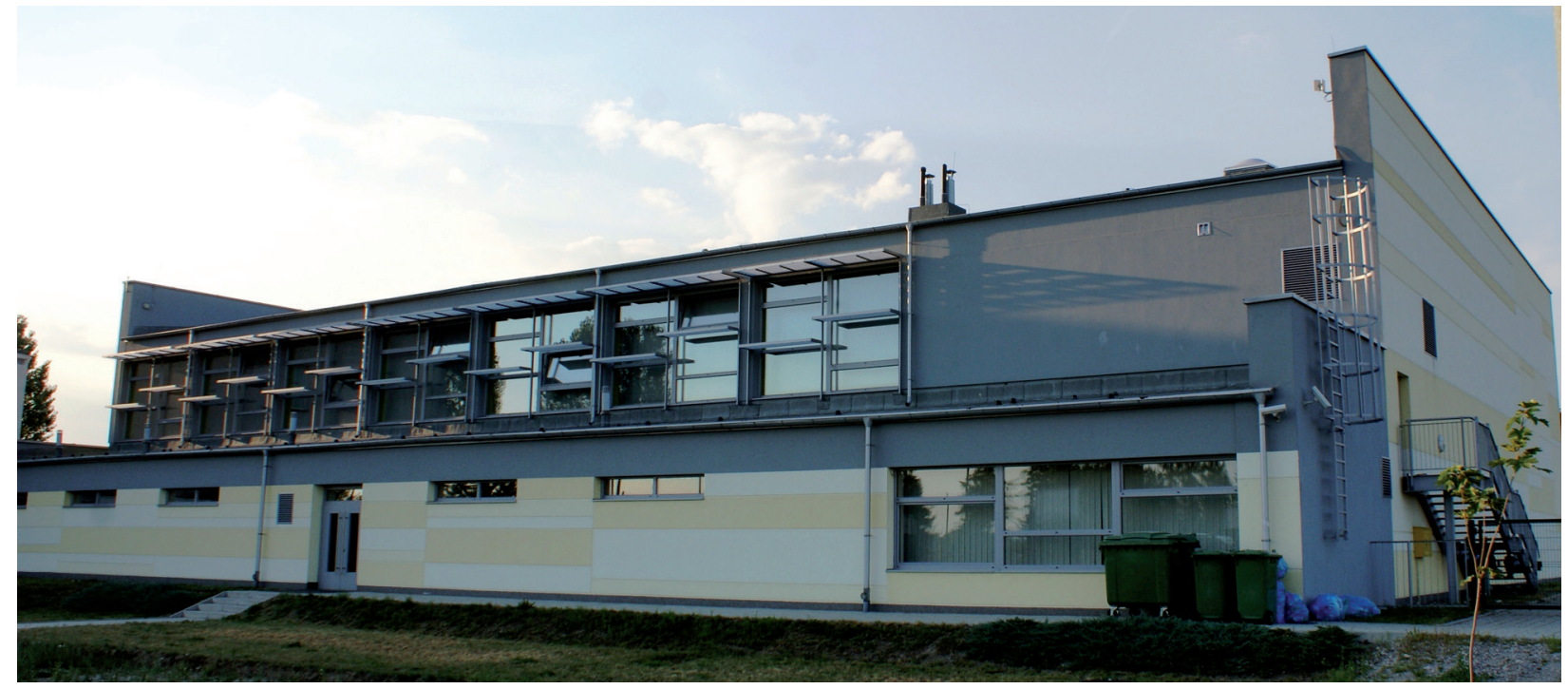

Photo 2. South view of the sports hall at Słomniki (Małopolska), the first passive public building in Poland with a quality certificate awarded by the Passive House Institute.

Source: photo by J. Chodkowska-Miszczuk, 18 August 2013. 
early 2011 at Słomniki in Małopolska voivodeship (http://www.innowacyjnapolska2010.pl; Photo 2).

\section{Data sources, research methods and determinants of energy efficiency improvement of public buildings in Poland}

This study was prepared using primary data obtained from the Local Data Bank of the Central Statistical Office (LDB CSO), the General Office of Building Control (GUNB), and the European Funds Portal (http:// www.funduszeeuropejskie. gov.pl), and secondary statistics derived from strategic documents and industry reports.

In the course of the research, methods of mathematical and statistical analysis were used (e.g. the coefficient of correlation), as well as various data visualisation methods (cartograms, cartodiagrams and graphs) to enhance its findings.

Because the domestic and EU regulations and financial instruments have increased the intensity of modernisation work in buildings in the recent years, the research covered the years 2007-2013, i.e. the period when EU funds were distributed through the Regional Operational Programmes for Voivodeships (ROPV). The first step in the research was to identify Polish towns where improvement projects subsidised by ROPV were carried out (as of 31 December 2012). As a result, a set of 193 towns was produced.

It has already been mentioned that the present-day situation of the Polish construction sector is determined by the laws in force, one source of which is the European Union. As an EU Member State, Poland is obligated, inter alia, to take measures improving the energy efficiency of buildings. In addition, public-sector entities have special tasks and responsibilities to fulfil in this area that arise from the existing regulations, which mobilises them to implement the concept of sustainable building. There are three major documents that need to be mentioned: the Directive on the energy performance of buildings of 16 December 2002 (2002/91/EC), the Directive on the energy performance of buildings of 19 May 2010
(2010/31/EC), and the Directive on energy efficiency of 25 October 2012 (2012/27/EU).

The requirements applying to the energy performance of buildings and the minimum quality standards are specified in the EU Directive on the energy performance of buildings (2002/91/EC) and updated in the Directive on the energy performance of buildings (2010/31/EC). Its provisions require that all new buildings meet the target of "almost zero energy consumption" by 31 December 2020, meaning that their demand for energy will have to be satisfied from the local sources of primarily renewable energy. All new buildings used or owned by public authorities will have to meet this target two years earlier, i.e. by 31 December 2018.

The next Directive on energy performance (2012/27/EU) requires that starting from January 2014 all public institutions should function as a benchmark in increasing the energy efficiency of buildings. Its provisions oblige the Member States to develop long-term strategies in support of projects undertaken to renovate the domestic stock of public buildings. They also require that $3 \%$ of the total area of heated and/or cooled buildings owned or occupied by government institutions be improved annually to the minimum standards applying to new buildings.

Therefore, the existing legal framework justifies raising the standard of the existing stock of public buildings to that of energy-efficient buildings. This process is supported, inter alia, by resources allocated by domestic and EU funds to thermal improvement projects increasing the energy efficiency of buildings.

\section{Characterisation of public buildings in Poland}

In the general structure of buildings in Poland, those used by the public do not exceed an average of 10\% (BuildDesk 2011). As far as the age of public buildings is concerned, almost $40 \%$ were built before 1960, 35\% in the years 1961-1990, and 25\% between 1991 and 2010 (BPIE 2011).

New public buildings are relatively few. In relation to the annual number of buildings put into service every year in the recent period, new 
public buildings account for an average of $6 \%$ (GUNB 2012). Public Buildings Construction in Poland (2012) forecasts that construction activity in the public sector will continue to shrink in the years to come, causing fewer and fewer new public buildings to be built. The situation has two sources: one is the saturation of the market with public buildings, and the other, improvements to their existing stock.

An analysis of public buildings in terms of their location reveals major spatial differences. In three voivodeships with the highest population density, i.e. Silesia, Wielkopolska and Mazovia, which together account for 35\% of all the Polish population (LDB CSO, 2012), distinct concentrations of new buildings are notable. The total number of public buildings handed over to users in these voivodeships in 2011 exceeded one-third of all public buildings completed in Poland (Fig. 1). It is noteworthy that Silesia, the most urbanised region in the country $(77.6 \%)$, is now going through a process of intense restructuring and

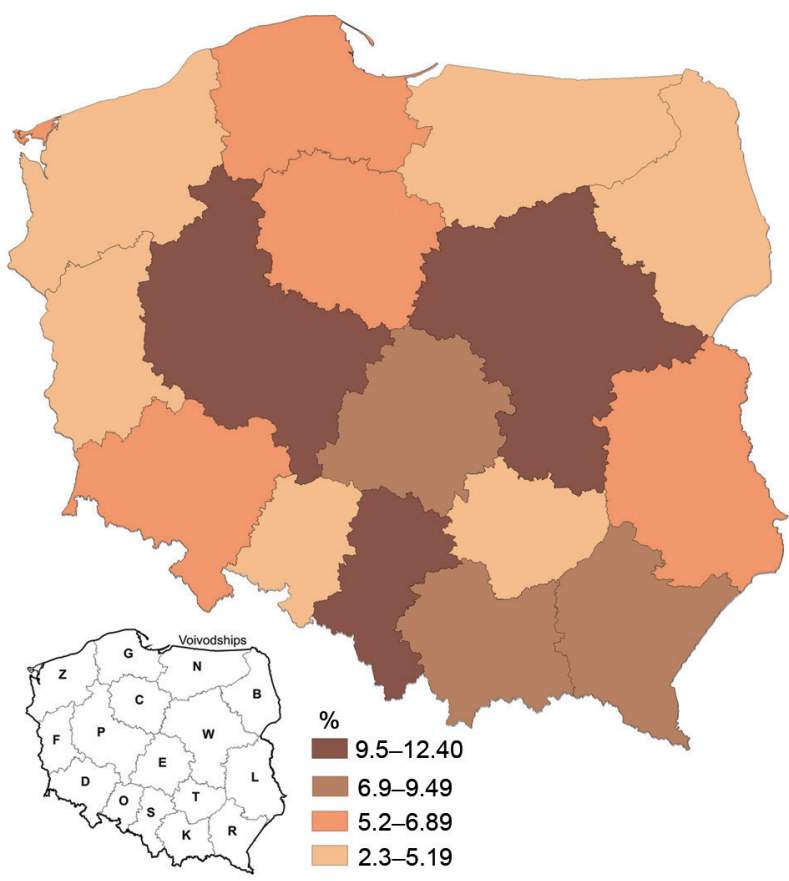

Fig. 1. Public buildings handed over to users in voivodeships as percentages of all public buildings put into use in Poland in 2011. Explanation:

Voivodeships: B - Podlasie; C - Kujavia-Pomerania; D - Lower Silesia; E - Łódź; F - Lubuska Land; G - Pomerania; K - Małopolska; L - Lublin; N - Warmia-Mazuria; O - Opole; P - Wielkopolska; R - Subcarpathia; S - Silesia; T - Świętokrzyska Land; W - Mazovia; $\mathrm{Z}$ - West Pomerania.

Source: developed by the authors on the basis of Ruch budowlany w 2011 r., GUNB, Warszawa. modernisation of its functions and the new functions (e.g. metropolitan) are a major factor in the supply of new public buildings.

As in other European states (BPIE 2011), public buildings in Poland are estimated to account for about $10 \%$ of all buildings in the country. It is therefore rational to assume that this rate is sufficient to satisfy residents' needs and to enable the delivery of public services. Some public buildings have become landmarks in the public space (e.g. the Palace of Culture and Science in Warsaw, Spodek (the Saucer) in Katowice, Manufaktura in Łódź, Stary Browar (the Old Brewery) in Poznań, Motoarena in Torun, Opera Nova in Bydgoszcz, etc.) and have gained the status of symbols shaping the image of their towns.

Public buildings have many uses and help towns fulfil many of their functions. An illustration of the wide array of functions they can perform is the definition included in the regulation of $12^{\text {th }}$ April 2002 issued by the Minister of Infrastructure (Official Gazette no. 75, position 690). A public building is defined as one used by public administration or the judiciary system, an establishment serving the purposes of culture, religious worship, schooling, higher education, science, upbringing, health-care, welfare or social aid, banking, trade, catering, services (including postal and telecommunication), tourism, sport, the handling of passengers using railway, road, air, sea or inland water transport, as well as other buildings performing similar functions; office buildings and social housing facilities are also considered public buildings. In Europe, facilities used for trading activity (28\%), offices (23\%) and educational establishments $(17 \%)$ have the largest shares in the structure of public buildings (BPIE 2011).

\section{Thermal improvement of public buildings in Poland as a way to raise their energy efficiency}

One of the main challenges faced by the building sector that entails adherence to sustainable development principles is the appropriate modernisation of buildings to increase their energy efficiency (Voss 2000). Many European countries 


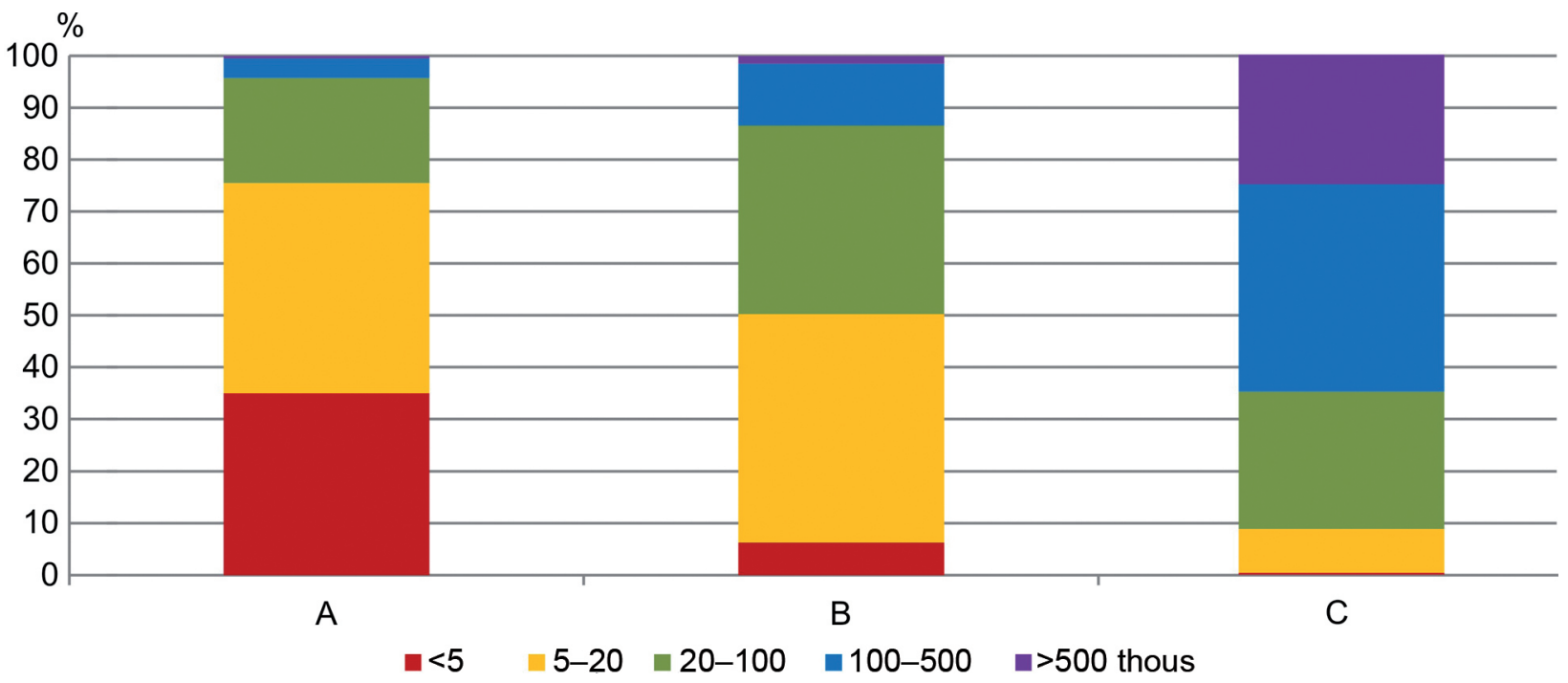

Fig. 2. Size structure of Polish towns as of 31 December 2012.

Explanation: A - percentage of Polish towns by size class; B - percentage of towns with TI projects in public buildings co-financed by the ROPV (2007-2013) by town-size class; C - percentage of population living in particular classes of towns where thermal improvement projects co-financed by the ROPV (2007-2013) were carried out in public buildings.

Source: developed by the authors on the basis of data available from the LDB CSO and European Funds Portal.

(e.g. France, Germany, Denmark, and Sweden) have found this activity important enough to address it in many strategic documents (Baek, Park 2012).

In Poland, too, buildings are being successively modernised, despite a smaller range of documents applying to this area. Modernisation projects quite clearly hang upon the availability of funds or the ability to raise them, policies pursued by local governments, and the environmental awareness of authorities and communities.

The pace and scope of modernisation works in public buildings are determined by the already mentioned legal and financial instruments, as well as by the availability of domestic and EU funding.

One of the relevant financial instruments used in Poland is the Thermo-Modernisation Fund established in 1998. Its resources were contributed by the state budget, and the entity responsible for their distribution is the Bank Gospodarstwa Krajowego (BGK). Eligible beneficiaries are those undertaking to reduce energy consumption in buildings. Over 16,000 projects worth more than 920 million zlotys had been completed by the end of 2009 (IEA 2011). Depending on the building type, average energy savings ranged from 36 to $65 \%$, public buildings being among those where they were the highest (53\%). The rising number of such projects indicates an increasing interest in improving the thermal efficiency of public buildings (Nowak 2010).

Another financial instrument used to fund TI projects in Polish towns, including those improving public buildings, was ROPV grants (20072013). At the end of 2012 TI projects in public buildings co-financed by the ROPV amounted to over 885 million zlotys, accounting for $1 \%$ of all ROPV-subsidised projects. For clarity, let us repeat that projects improving public buildings are considered in this article in terms of their location, value, sources of funding (including EU subsidies), and use.

When ROPV co-funded TI projects in public buildings are considered by their location (as of 31 December 2012), a set of 193 towns is produced ( $21 \%$ of all towns in the country). More than half of them have populations of up to 20,000 and those with more than 100,000 residents make up over $13 \%$. The size structure of the 193 towns and that of all Polish towns have similar percentages of small units with populations from 5,000 to 20,000 (Fig. 2).

An analysis of the 193 towns in terms of their number in particular voivodeships shows that in four - Opole, Silesia, Subcarpathia and Pomerania - the rates of those with ROPV-subsidised TI projects exceeded $40 \%$ of all towns in the voivodeship. Interestingly, in two voivodeships, Warmia-Mazuria and West Pomerania, not a sin- 


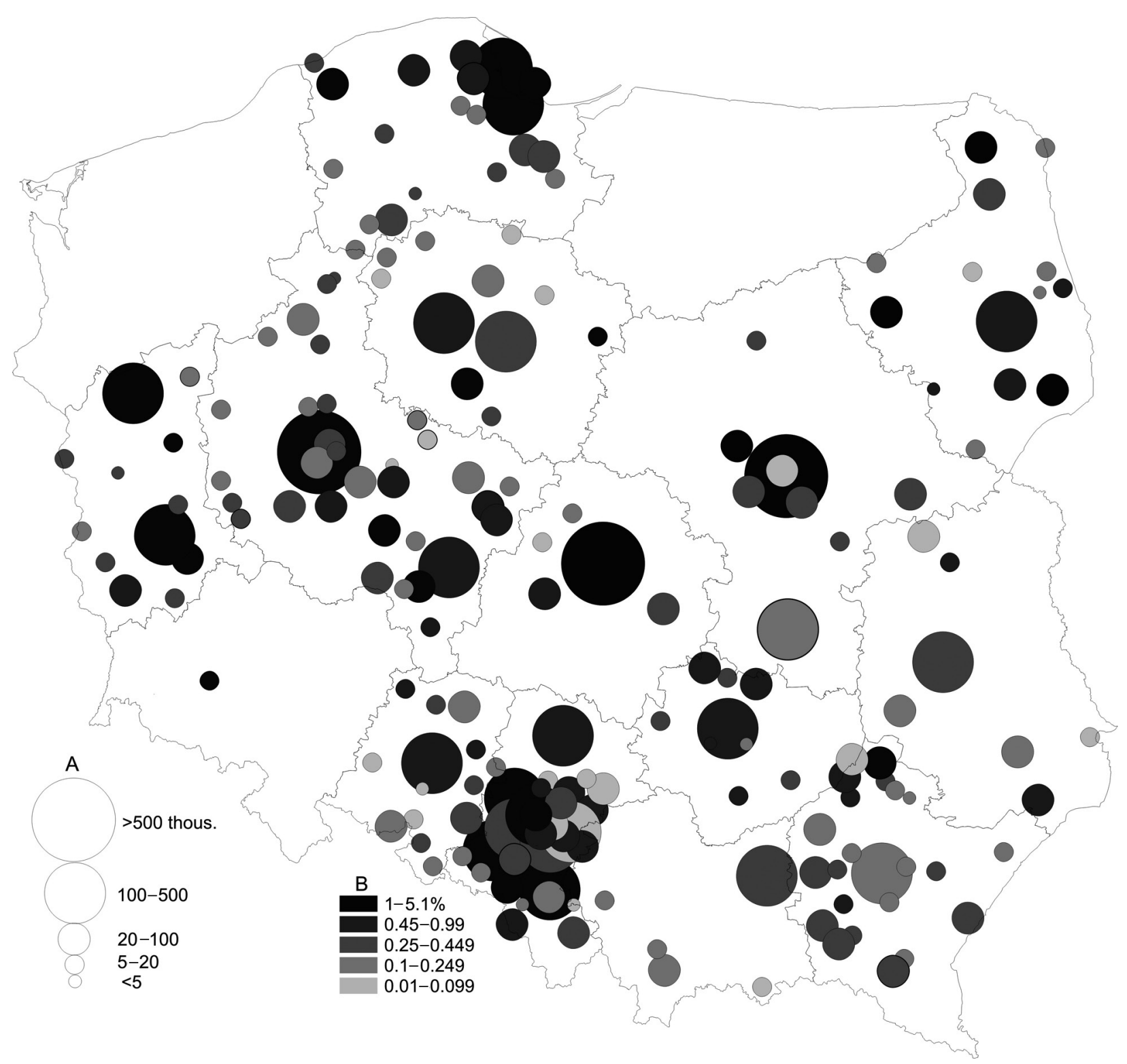

Fig. 3. TI projects involving public buildings in Polish towns as percentages of the total value of TI projects co-funded by the ROPV (2007-2013), as of 31 December 2012.

Explanation: A - town-size structure by population number; B - TI projects involving public buildings subsidised by the ROPV (2007-2013) as percentages of the total value of TI projects.

Source: developed by the authors on the basis of data available from the LDB CSO and European Funds Portal.

gle town or city had a TI project subsidised by the ROPV.

When analysing TI projects by their value, we find that the most expensive ones were mainly carried out in Silesian and Wielkopolska towns. The two voivodeships accounted for $37.5 \%$ of the total value of TI projects $(23.2 \%$ and $14.3 \%$, respectively). Most of the largest projects can be found in the biggest Polish cities, i.e. Katowice, Sosnowiec, Zabrze, Poznań, Gdańsk, Warsaw, and Łódź (Fig. 3), where project values ranged between ten and twenty million zlotys, and in the case of Katowice even exceeded 40 million. The population number in a town and the value of its TI projects are correlated: the larger the population, the more expensive the project. This relationship is also confirmed by the correlation coefficient: $r=0.536$ at $p<0.05$.

As regards the sources of means used to fund TI projects, the EU backup must be acknowledged as significant. The greatest support was mainly directed to small-scale projects. EU grants covering $80 \%$ or more of costs went to undertakings estimated at an average of 2.7 mil- 


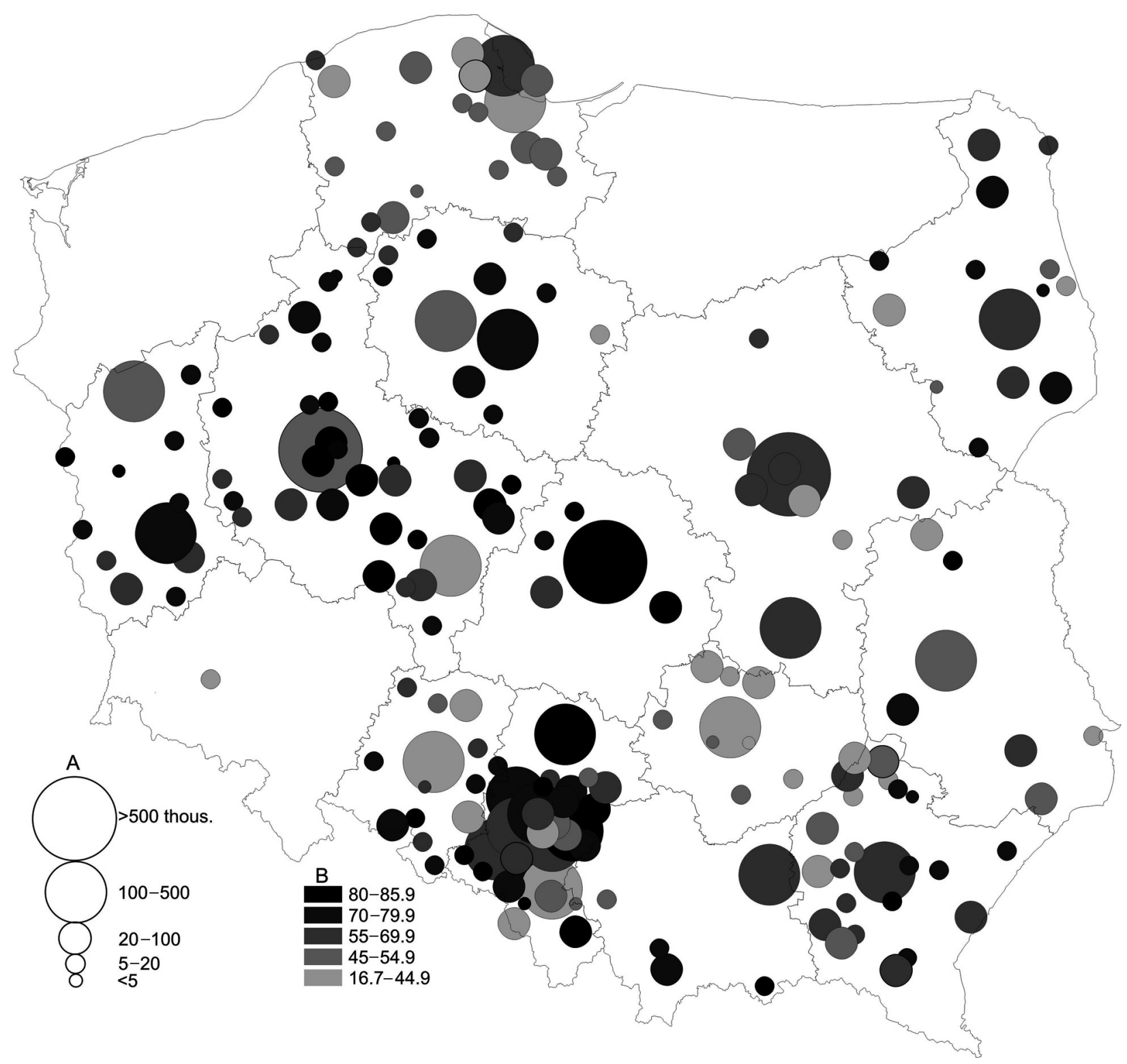

Fig. 4. EU's financial contribution to TI projects involving public buildings in Polish towns subsidised by the ROPV (20072013), as of 31 December 2012.

Explanation: A - town-size structure by population number; B - EU's financial contribution to thermal improvement projects involving public buildings in Polish towns subsidised by the ROPV (2007-2013).

Source: developed by the authors on the basis of data available from the LDB CSO and European Funds Portal.

lion zlotys. This finding is also confirmed by the coefficient of correlation between project costs and the EU funding awarded $(r=-0.208, p<$ 0.05). A pattern can be observed: the smaller the project value, the more EU funding awarded to works improving thermal characteristics of public buildings in the analysed Polish towns. It is notable that about $70 \%$ of the towns benefiting from the largest EU grants $(80 \%$ or more of total project costs) were in Silesia and Wielkopolska (Fig. 4), where the projects were also the most expensive (cf. Fig. 3).
An analysis of the value of TI projects carried out in public buildings shows a significant role of local governments in their creation and implementation. The use of innovative solutions is clearly related not only to the already discussed legal and financial instruments, but also to endogenous resources, particularly human capital accumulated in local governments (Szymańska, Chodkowska-Miszczuk 2011). It is local authorities, including municipal councils, that make decisions on where IT projects will be conducted and what their value will be. They are also re- 


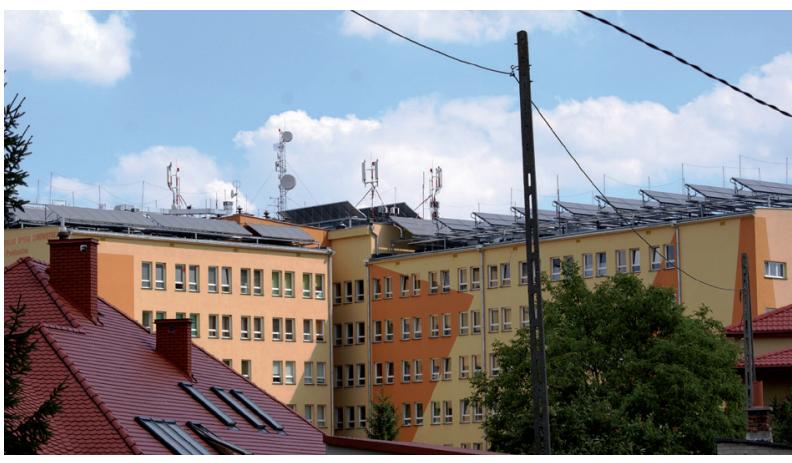

Photo 3. Independent Public Health-Care Centre at Radzyń Podlaski (Lublin voivodeship). An example of a TI project co-funded by the ROPV (2007-2013) in a town of up to 20,000 population.

Source: photo by J. Chodkowska-Miszczuk, 11 August 2013.

sponsible for raising means from available sources, including EU funds. The research has shown that the younger the councillors on a municipality council (aged 25-30), the higher the project value $(r=0.315, p<005)$. Knowledge, experience and skills are also important in the preparation of projects. These human characteristics are quite clearly tied to the level of educational attainment, which explains why the number of councillors with tertiary education and the value of a TI project are correlated, and why a greater number of such councillors translates into higher project values $(r=0.411, p<0.05)$.

As regards the use of public buildings chosen for TI projects, most of them delivered a town's basic functions; they were also the most burdensome for local budgets to maintain. Thus, $44.3 \%$ of them were educational establishments (kindergartens, schools, community centres), 22\% were health-care facilities (hospitals, outpatient clinics; Photo 3), and about $12 \%$ were used by public administration (central or local) (Fig. 5).

It was found that voivodeships differed in the type of use of public buildings where TI projects were implemented (Fig. 6). For example, while in Łódź voivodeship over $87 \%$ of the projects involved educational establishments, in Świętokrzyska Land almost $60 \%$ were carried out in buildings used by public administration.

\section{Conclusions}

The research results show that projects addressing the thermal efficiency of buildings are

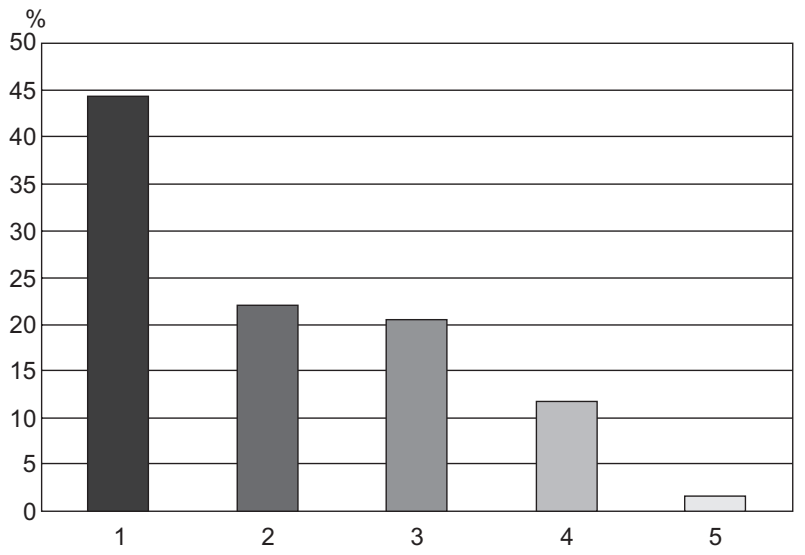

Fig. 5. Use structure of public buildings in Polish towns where TI projects were subsidised by the ROPV (20072013), as of 31 December 2012.

Explanation: 1 - educational establishments, 2 - health-care establishments, 3 - other public facilities ${ }^{1}, 4$ - public administration buildings, 5 - child-care establishments.

Source: developed by the authors on the basis of data available on the European Funds Portal.

one of the ways to implement the sustainable building concept and increase the energy efficiency of public buildings in Polish towns.

An analysis of the modernised buildings by their use reveals that most TI projects, as much as $44.3 \%$, involved educational establishments (kindergartens, schools, community centres), then health-care facilities (hospitals, outpatient clinics), and buildings used by public administration. The buildings are needed by the towns to deliver basic municipal services, but they are also the most burdensome for local budgets in terms of maintenance costs.

Another finding has been that TI projects were unevenly distributed among Polish towns. Projects subsidised from EU funds under the 2007-2013 ROPV were carried out in 193 of them ( $21 \%$ of their total number in the country). The most expensive projects were implemented in the largest cities. As observed, the value of a project tended to increase with the city's population.

As regards the distribution of TI projects among voivodeships, most projects (and the most costly ones) were carried out in two most populous regions of the country, Wielkopolska and Silesia. The two voivodeships account between them for $37.5 \%$ of the total value of pro-

Other buildings used by the public, including buildings of public worship, industrial structures, retail and service facilities. 


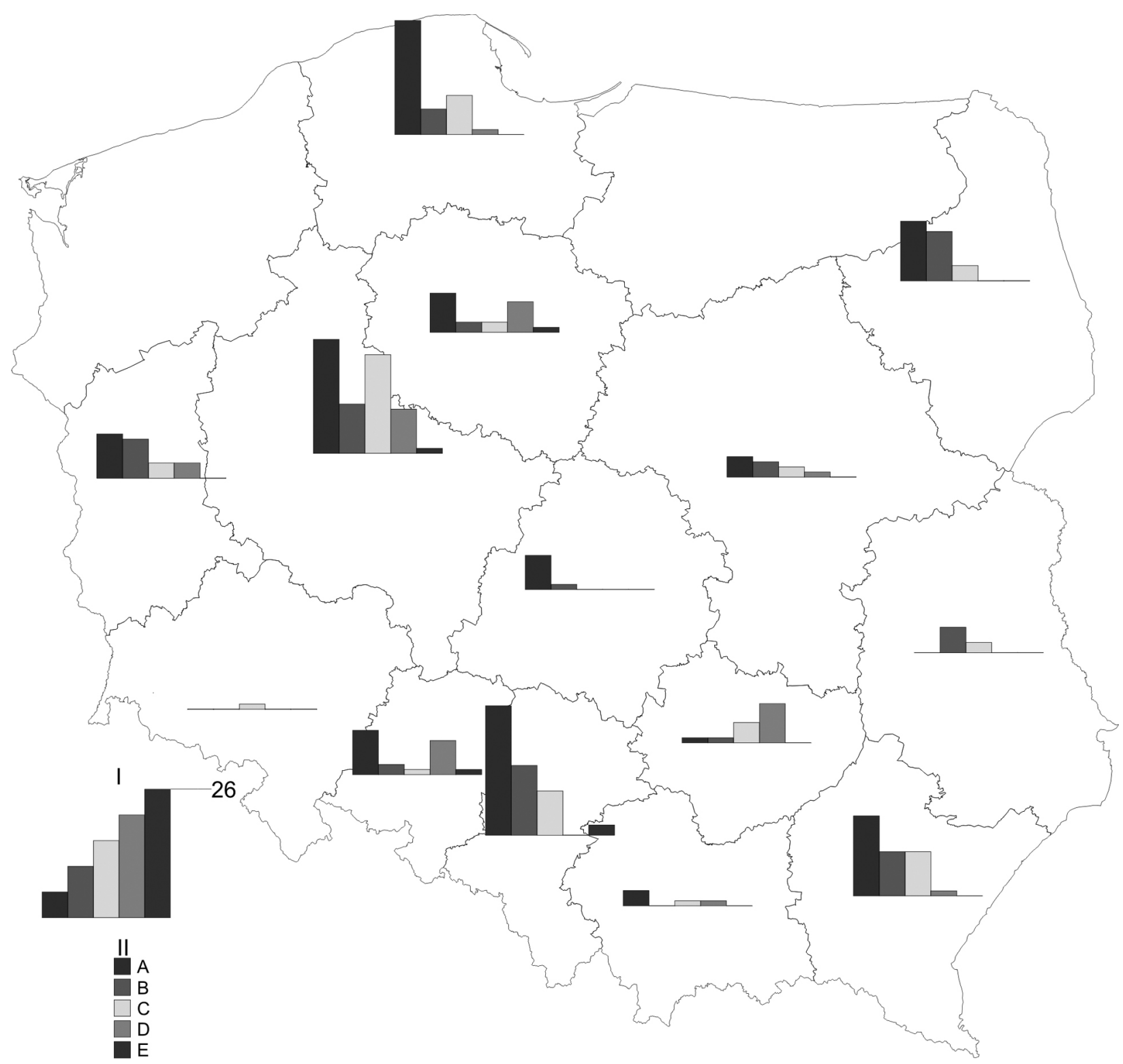

Fig. 6. Number and use structure of public buildings in Polish towns where TI projects were subsidised by the ROPV (2007-2013), as of 31 December 2012; by voivodeship.

Explanation: I - number of public buildings; II - use structure of public buildings: A - educational establishments, B - health-care establishments, C - other public facilities (see note 1), D - public administration buildings, E - child-care establishments. Source: developed by the authors on the basis of data available on the European Funds Portal.

jects under consideration. An interesting finding has been that the largest amounts of EU funding (covering $80 \%$ and more of project costs) were given to projects of under 3 million zlotys.

The overall trends, including the present policy of the EU and the age structure of public buildings in Poland (75\% of which were erected before 1990), imply that the number of IT projects will rise. The incentive will be, as has been so far, the availability of domestic and EU funding. The pace and scope of activity will be determined by the resourcefulness of local governments.

\section{Acknowledgements}

This paper was written thanks to the financial support under grant No. 1695-G for young researchers from the Faculty of Earth Sciences, Nicolaus Copernicus University, Torun. 


\section{References}

Baek Ch., Park S., 2012. Policy measures to overcome barriers to energy renovation of existing buildings. Renewable and Sustainable Energy Reviews 16 (6): 3939-3947.

Bank Danych Lokalnych Gtównego Urzędu Statystycznego (Local Data Bank of the Central Statistical Office, LDB CSO), 2012. Online: www.stat.gov.pl (accessed 12 May 2013).

BPIE, Buildings Performance Institute Europe, 2011. Europe's buildings under the microscope. A country-by-country review of the energy performance of buildings 2011. BPIE, Brussels.

BuildDesk Polska, 2011. Raport: stan energetyczny budynków w Polsce (Report on the energy state of buildings in Poland). Builddesk, Cigacice.

Chodkowska-Miszczuk J., Szymańska D. 2012. Technologie słoneczne szansą promocji regionu? (Solar technologies as a chance to promote a region?). Polska Energetyka Stoneczna 1-4: 63-68.

Coimbra J., Almeida M., 2013. Challenges and benefits of building sustainable cooperative housing. Building and Environment 62: 9-17.

Commission of the European Community, 2007a. Communication from the Commission to the Council, the European Parliament, the European Economic and Social Committee and the Committee of the Regions. A lead market initiative for Europe. COM (2007), 860. Brussels.

Commission of the European Community, 2007b. Commission Staff Working Document, Annex I to the Communication from the Commission to the Council, the European Parliament, the European Economic and Social Committee and the Committee of the Regions. A Lead Market Initiative for Europe. SEC (2007), 1729. Brussels.

Directive on the energy performance of buildings of 16 December 2002 (2002/91/EC), L 1/65.

Directive on the energy performance of buildings of 19 May 2010 (2010/31/EC), L 153/13.

Directive on energy efficiency of 25 October 2012 (2012/27/EU), L 315/1.

GUNB, Główny Urząd Nadzoru Budowlanego, 2012. Ruch budowlany w 2011 roku (Construction activity in 2011). GUNB, Warszawa.

GUS (Central Statistical Office), 2011. Energy statistics 2009, 2010. GUS, Warsaw.
Hepbasli A., 2012. Low energy (LowEx) heating and cooling systems for sustainable buildings and societies. Renewable and Sustainable Energy Reviews 16: 73-104.

http:/ / www.innowacyjnapolska2010.pl/component/content/article/16-otwarcie-hali-sportowej-w-somnikach. html (accessed 11 July 2013).

IEA, International Energy Agency, 2010. Energy technology perspectives 2010. Scenarios and strategies to 2050. OECD and IEA, Paris.

IEA, International Energy Agency, 2011. Polityki energetyczne państw MAE. Polska 2011 - Przegląd (Energy policies of IEA countries. Poland 2011 - A review). OECD and IEA, Paris.

Juan Y-K., Gao P., Wang J., 2010. A hybrid decision support system for sustainable office building renovation and energy performance improvement. Energy and Buildings 42 (3): 290-297.

Nowak H., 2010. Zagadnienia istotne dla Polski w ramach tematyki budynków efektywnych energetycznie (Issues relevant to Poland on the theme of energy efficient buildings). Inicjatywa Europejska Budynków Efektywnych Energetycznie, Warszawa.

Passivhaus Institut. Online: http://passiv.de (accessed 11 July 2013).

Portal Funduszy Europejskich. Online: http:/ / www.funduszeeuropejskie.gov.pl (accessed 5 May 2013).

Public buildings construction in Poland, 2012 - Development forecasts for 2012-2015. Online: http://www.pmrpublications.com/free_stuff/1171/record-high-18bn-to-bespent-on-the-construction-of-public-buildings-in-poland-in-2012-october-2012 (accessed 1 July 2013).

Szymańska D., 2013. Geografia osadnictwa. Wydanie II (Settlement geography, 2nd edition). Wydawnictwo Naukowe PWN, Warszawa. http:// repozytorium.umk.pl/ handle/ item/1025.

Szymańska D., Chodkowska-Miszczuk J., 2011. Update of the review: Cultivation of energy crops in Poland against socio-demographic factors. In: Renewable and Sustainable Energy Reviews 15 (9): 4242-4247. DOI: http:// dx.doi. org/ 10.1016/ j.rser.2011.07.126.

Voss K., 2000. Solar energy in building renovation - results and experience of international demonstration buildings. Energy and Buildings 32: 291-302.

Zmeureanu R., 2006. Sustainable buildings: dream or reality? Journée Thématique SFT-IBPSA; March 2006. 